УДК 378.091 .33

DOI:

Оксана Микитюк, доктор педагогічних наук, професор кафедри суспільно-гуманітарних наук Української академії друкарства; доктор педагогічних наук, доцент кафедри технології біологічно активних сполук, фармачї та біотехнології НУ “Львівська політехніка"

Роксоляна Конечна, кандидат фармацевтичних наук, доцент кафедри технології біологічно активних сполук, фармації та біотехнологї НУ “Львівська політехніка”

Ольга Швед, кандидат хімічних наук, доцент кафедри технологї біологічно активних сполук, фармації та біотехнології НУ “Львівська політехніка"

Галина Никитюк, кандидат медичних наук, дочент кафедри патологічної фізіологї ЛНМУ імені Д. Галииького

Анна Крвавич, кандидат технічних наук, асистент кафедри технології біологічно активних сполук, фармації та біотехнології НУ “Львівська політехніка”

Володимир Новіков, доктор хімічних наук, професор, завідувач кафедри технологї біологічно активних сполук, фармації та біотехнології НУ “Львівська політехніка”

\title{
ШЛЯХИ СТВОРЕННЯ ЕКОЛОГООРІЕНТОВАНОГО ОСВІТНЬОГО СЕРЕДОВИЩА У ЗАКЛАДАХ ВИЩОЇ ОСВІТИ
}

Проблематика напрямів реалізації створення екоогоорієнтованого освітнього середовища у навчальному закладі потребує дослідження. Не випадково останнім часом зростає роль вищої школи як соціального інституту, що формує не тільки компетентного спеціаліста, але й повноцінну, здорову особистість з такими сформованими якостями і властивостями особистості як соиіоекологічна активність, з орієнтаиією на екологоорієнтований спосіб життя. У статті розглядається проблематика напрямів створення екологоорієнтованого освітнього середовища у закладах вищої освіти. Таким чином, виявлені нами особливості організації і створення екологоорієнтованого освітнього середовища у вузі передбачають необхідність розробки та реалізації структурно-функиіональної моделі організаиії екологоорієнтованого освітнього середовища у закладі вищої освіти, що включає в себе створення сучасного освітнього середовища з елементами екологоорієнтованості у $3 B O$ з метою підвищенням конкурентоспроможності професійної освіти. Кінцева мета - проектування ЗВО як иеенту простору інноваційного освітнього середовища.

Ключові слова: освітне середовище; освітній прочес; сприятливе екосередовище; особливості організації екологоорієнтованого освітнього середовищя.

Лim. 14.

Oksana Mykytyuk, Doctor of Sciences (Pedagogy), Professor of the Social and Humanitarian Sciences Department, Ukrainian Academy of Printing;

Doctor of Sciences (Pedagogy), Associate Professor of the Technology of Biologically Active Substances, Pharmacy and Biotechnology Department, Lviv Polytechnic National University Roksolana Konechna, Ph.D.(Pharmacy), Associate Professor of the Technology of Biologically Active Substances, Pharmacy and Biotechnology Department, Lviv Polytechnic National University Olha Shved, Ph.D.(Chemistry), Associate Professor of the Technology of Biologically Active Substances, Pharmacy and Biotechnology Department, Lviv Polytechnic National University Anna Krvavych, Ph.D.(Technical), Associate Professor of the Technology of Biologically Active Substances, Pharmacy and Biotechnology Department, Lviv Polytechnic National University

Halyna Nykytyuk, Ph.D.(Medicine), Associate Professor of the Pathological Physiology Department, National Danylo Halytskiy Medical University of Lviv

Volodymyr Novikov, Doctor of Sciences (Chemistry), Pprofessor, Head of the Technology of Biologically Active Substances, Pharmacy and Biotechnology Department,

Lviv Polytechnic National University

\section{WAYS OF CREATION OF ECOLOGICALLY ORIENTED EDUCATIONAL ENVIRONMENT IN HIGHER EDUCATION INSTITUTIONS}

The problem of health maintenance of the young and growing generation is one of the global problems of modern society. This problem is relevant for both preschool and school education, as well as for the student 


\section{ШЛЯХИСТВОРЕННЯ ЕКОЛОГООРІЄНТОВАНОГООСВІТНЬОГО СЕРЕДОВИЩА У ЗАКЛАДАХ ВИЩОЇ ОСВІТИ}

environment, because the negative ecological condition of the environment, incomplete performance of the health care system, and the low living standarts in the families lead to health problems of children from the moment of birth.

By the end of the 2000, Ukraine has passed the stage of an industrial society and is entering a postindustrial, information society, where the human factor comes first. At the same time, the modern educational level, working conditions and the increasing intensity of mental activity require from the specialist not only the appropriate qualification, but also a high educational and cultural level. Problems of realization and creation of eco-oriented educational environment in educational institution are investigated only partially. It is no doubt that the role of higher education as a social institute, which forms not only a competent specialist, but also a self-sufficient, healthy personality with such qualities and personality traits as socio-ecological activity, orientation to an environmentally oriented lifestyle.

This article describes the ways to resolve such problem as realization and creation of ecologically oriented educational environment in higher education institutions. The peculiarities of our organization and creation of ecologically oriented educational environment in the university imply the necessity of development and realization of structural and functional model of organization of ecologically oriented educational environment in higher education. Creation of a modern educational environment with elements of environmental orientation in the Higher education Instititions; increasing the competitiveness of education; designing Higher education Instititions as place centers for creating an eco-oriented innovative educational environment.

Keywords: an educational environment; an educational process; favorable eco-environment; peculiarities of organization of ecologically oriented educational environment.

П остановка проблеми. Проблема збереження здоров'я підростаючого покоління є однією 3 глобальних проблем сучасного суспільства. Зазначена проблема актуальна як для дошкільної, і шкільної освіти, так і для студентського середовища, адже негативний екологічний стан навколишнього середовища, недостатня ефективність системи охорони здоров'я, зниження життєвого рівня родин провокують погіршення здоров'я дітей від самого народження.

Україна до кінця другого тисячоліття пройшла стадію індустріального суспільства і вступає в постіндустріальне, інформаційне суспільство, де на перше місце виходить людський фактор. При цьому сучасний освітній рівень, умови праці і все зростаюча напруженість розумової діяльності вимагають від фахівця не лише відповідної кваліфікації, високого освітнього та культурного рівня, а й міцного здоров'я, гарної фізичної та функціональної підготовленості, високих моральних i вольових якостей $[3,4]$. Проблематика шляхів реалізації створення екоогоорієнтованого освітнього середовища у навчальному закладі досліджена лише частково. Не випадково останнім часом зростає роль вищої школи як соціального інституту, що формує не тільки компетентного спеціаліста, але й повноцінну, здорову особистість 3 такими сформованими якостями і властивостями особистості як соціоекологічною активністю, орієнтація на екологоорієнтований спосіб життя. У дослідженні розглядається проблематика реалізації створення екологоорієнтованого освітнього середовища у закладах вищої освіти. Виявлені нами особливості організації і створення екологоорієнтованого освітнього середовища у вузі передбачають необхідність розробки та реалізації структурно-функціональної моделі організації екологоорієнтованого освітнього середовища у закладі вищої освіти, що включає в себе створення сучасного освітнього середовища з елементами екологоорієнтованості у ЗВО для підвищенням конкурентоспроможності професійної освіти і з проектування ЗВО як центрів створення екологоорієнтованого інноваційного освітнього середовища.

Мета, завдання. Метою нашого дослідження $€$ намагання сформулювати виклики і окреслити шляхи реалізації створення екологоорієнтованого освітнього середовища у закладах вищої освіти.

Результати дослідження та їх обговорення. Згідно визначення в педагогічному словнику, "середовище педагогічне - це спеціально створена відповідно до педагогічних цілей система організації життедіяльності дітей, спрямована на формування їхнього ставлення до світу, людей i один до одного [2, 142]. У дослідженнях феномену педагогічного середовища науковці визначають це поняття як “освітнє середовище" (В.А. Ясвін), "навчальне та виховуюче середовище" (Г.Б. Корнетов), "навчальне культурне середовище” (С.Ф. Сергєєв).

Згідно 3 ідеями В.А. Ясвіна, освітне середовище (або середовище освіти) є “системою впливів та умов формування особистості за заданим зразком, а також можливостей для ії розвитку, які має соціальне та просторовопредметне оточення" [9, 14]. Науковець Г.Б. Корнетов вважає, що освітнє середовище це той виховний простір, в якому здійснюється педагогічно організований розвиток особистості. С.Ф. Сергєєв розглядає середовище як дійсність, представлену процесом конструювання взаємин 
людини з реальністю. Науковець висловлює думку, що основним іiі механізмом є “взаємодія учасників педагогічного процесу між собою в межах шкільної організації зі спеціально організованою системою засобів та методів, які зберігають і відображають культурний досвід людства у певній сфері знання з метою набуття особистого досвіду для спрямованої модифікації поведінки" $[5,7]$.

Характеристику природи освітнього середовища, його багатофакторність і багатокомпонентність вказує також і О. Артюхіна, досліджуючи його як цілісність, що має три структурні рівні організації: - освітнє середовище як динамічна цілісність, що інтегрує взаємодію просторових відносин архітектурного, матеріально-технічного, соціокультурного (гуманітарного), інформаційного, педагогічного середовищ; - освітнє середовище як сукупність побудованих за концентричним принципом компонентів: освітнє середовище кафедри, факультету, курсу, групи, середовище установи, в якій реалізується освітньо-виховний процес; - освітнє середовище вищого навчального закладу як духовна спільність, що постає в міжсуб'єктній взаємодії і сприяє професійноособистісному становленню майбутнього фахівця. Причому своєрідним стрижнем освітнього середовища $є$ ціннісна спільність і традиції вищого навчального закладу [1, 40 - 5].

У психолого-педагогічній літературі поняття “освітне середовище” іноді ототожнюють 3 поняттям “освітній простір”. Остання дефініція у педагогічній термінології з'явилась лише наприкінці 1980-х років. Багато сучасних учених уважають, що середовище (освітнє, розвивальне, етновиховне, інформаційно-комунікаційне тощо) $\epsilon$ складовою частиною простору (відповідно освітнього, розвивального, соціокультурного, етновиховного) (О. Будник, Р. Малиношевський, В. Радул, О. Сергієнко, О. Смолінська та ін.). Характеризуючи відмінність між освітнім простором та освітнім середовищем, О. Артюхіна наголошує на часовому чиннику, тобто саме остання категорія (середовище) відзначається мінливістю та тривалістю в часі. Власне, на думку вченої, поняття “простір" передбачає впорядкованість певних систем, водночас “середовище” більшою мірою стосується низки чинників, умов, які або безпосередньо стосуються людини, що є суб'єктом освітнього середовища, або ж $є$ нейтральними до нього [2, $47-48]$. Нам імпонує твердження вченої про те, що в середовищі, на відміну від простору, є більш сприятливі можливості для індивідуалізації особистості, передусім, це стосується навчально- виховного процесу.

Досліджуючи у науковій літературі поняття навчального середовища, С.Г. Литвинова розглядає також такі поняття, як середовище, навчальне середовище, інформаційно-освітнє середовище, освітнє середовище, мережне середовище навчання, віртуальне навчальне середовище, персональне навчальне середовище. Автор визначає навчальне середовище закладу загальної середньої освіти як “спеціально організоване захищене, відкрите середовище, у якому створюються умови рівного доступу до освіти всіх учасників навчально-виховного процесу", використання якого спрямовано на набуття ними певних знань, умінь, навичок.

Б.В. Олейніков [7] стверджує, що в час широкого використання сучасних інформаційних технологій, на основі якого визначаються нові види взаємовідносин і взаємодії, основним $є$ середовище, що включає всі науковотехнічні досягнення. Мова йде про концепцію навчання "Learning Ecosystem" (“Екосистема навчання"), де використовуються основні закони існування, властиві як природі так і (і штучним) екосистемам $[10,14]$. У будь-якій екосистемі живі організми взаємодіють з будь-яким іншим суб'єктом в їх спільному навколишньому середовищі. Відповідно до цього положення екосистема навчання відноситься до інтегрованого середовища, де всі суб'єкти: здобувачі освіти, вчителі, адміністратори, батьки взаємодіють один $з$ одним, а також використовують велику кількість інноваційних продуктів, технологій, методик навчання і інших елементів екосистеми навчання, через які визначаються умови навчання. Замість обміну енергією між компонентами природньої екосистеми в екосистемі навчання, вважає Б. Олейніков, відбувається обмін даними. Передбачається, що така екосистема може перебувати в безперервному розвитку. До теми екосистема навчання звертались і закордонні дослідники [5; $6 ; 8 ; 9 ; 11 ; 12]$, які розглядали побудову такої системи на основі сучасних технологій.

Термін “екологія”, що був запропонований Е. Геккелем у 1869 році, і лише на сьогоднішній час прийшло розуміння, що будь яке середовище, в якому знаходиться людина - це їі дім, i відповідно взаємодія з середовищем перебування підлягає екологічним законам. Відповідно в наукове співтовариство, освітню, професійну i соціальну діяльність ввійшли нові терміни “екологічна психологія”, “екологічна педагогіка”, “екологічна культура”, “соціоекологія” і поняття “екологія освіти” (навчання, виховання, розвитку), “екологія здоров'я” “екологія інновацій”, “екологія 


\section{ШЛЯХИСТВОРЕННЯ ЕКОЛОГООРІЄНТОВАНОГО ОСВІТНЬОГО СЕРЕДОВИЩА У ЗАКЛАДАХ ВИЩОЇ ОСВІТИ}

освітнього середовища”, “створення сприятливого екосередовища" [8; 9; 11; 12]. Відповідно, вони стали платформою для багаточислених досліджень в різних галузях науки. В рамках заявленої нами теми, можна окреслити наступні напрями дослідження:

1. Створення сучасного освітнього середовища з елементами екологоорієнтованості у ЗВО;

2. Підвищення конкурентоспроможності ЗВО;

3. Проектування ЗВО як центрів створення екологоорієнтованого інноваційного освітнього середовища.

Почнемо з особливостей створення сучасного освітнього середовища.

Ми розглядаємо створення сучасного освітнього середовища не 3 точки зору інформаційно-віртуального середовища, оснащення сучасним інноваційним обладнанням і приладами, 3 впровадженням ефективних інноваційних освітніх технологій, хоча ці питання, без сумніву, важливі при вирішенні проблеми створення сучасного освітнього середовища. Фактично освітній процес, є процесом занурення у віртуальний світ, актуалізація потенційних “можливостей” і проектування себе у майбутньому. Ми вважаємо, що сучасна освітнє середовище, в якому перебуває студент, якого навчають, повинно бути також і його “житлом”, комфортно-доступним і створювати умови для гармонійного розвитку особистості. Ми у попередніх працях зупинялись на аспектах створення сприятливого екосередовища “здорова школа-сприятливе екосередовище”, зокрема 3 лікарських рослин у школі [6].

Розгляд питань створення сучасного освітнього середовища, з нашої точки зору, неможливо без розгляду особливостей екологоорієнтованого освітнього середовища, створення якого і взаємодія з яким повинно підпорядковується екологічним законам. Безсумнівний інтерес для екологоорієнтованого освітнього середовища має група законів, об'єднаних в екології під загальною назвою як закони Б. Коммонера [13].

На наш погляд, доцільно виокремити екологічні закони, які важливі для дослідження особливостей екологоорієнтованого освітнього простору. Базовий закон будь-якої екологічної системи - це закон розвитку. Відповідно до даного закону будьяка екологічна система може розвиватися тільки за рахунок створення i використання матеріальних, енергетичних, інформаційних, соціальних можливостей навколишнього їі середовища. Абсолютно ізольований саморозвиток системи є неможливий. Відповідно до цього екологічного закону розвиток освітнього середовища стикається з певними складнощами, оскільки має декілька рівнів існування - від всеукраїнського і обласного і до кінцевого основного свого першоелементу - освітнього середовища конкретного ЗВО, тому розвиток залежить від об'єднання можливостей усіх рівнів в єдиний освітній простір екологоорієнтованого розвитку.

Наступним екологічним законом, важливим для формування екологоорієнтованого освітнього середовища є закон єдності. Цей закон вказує на те, що у успішно функціонуючій екологічній системі все є поєднано і взаємоповязано. Тобто, якщо $є$ небезпека для одного сегменту екологічної системи, то це $\epsilon$ небезпечним для інших елементів екологічної системи. 3 точки зору створення екологоорієнтованої освітньої системи варто наголосити, що єдність при різноманітті компонентів освітньої системи повністю виключає присутність екологоруйнуючих, деструктивних елементів [11].

Для вирішення нагальних завдань формування екології освітнього середовища важливий екологічний закон взаємозв'язку. Даний закон сформульований наступним чином: “Все пов'язано з усім” [11]. Відповідно, цей екологічний закон концентрує увагу на обов'язковому взаємозв'язку процесів, взаємодій для успішного функціонування будь-якої екологічної системи. Тому створення освітньої системи, яка динамічно змінюється, але якій властива внутрішня стійкість, дозволяє створити екологоорієнтовану освітню систему, яка стане комфортним місцем перебування для всіх учасників освітнього процессу.

Наступний важливий екологічний закон - це закон знання, який Б. Коммонер коротко сформулював наступним чином: “Природа знає краще”. На функціонування освітнього середовища впливає багато факторів - соціальних, особистісних, матеріальних, фінансовоекономічних та інших. Однак стосовно соціоеколоорієнтованої системи, якою повинна бути освітня система, це застереження діє так само, як і до системи у живій природі. І в природі, і в соціумі основою розвитку є “носії інформації”. Тому успішне і ефективне функціонування освітньої системи з точки зору екологоорієнтованості неможливе, поки у системі не налагоджена система збору, зберігання і передачі достовірної інформації. Всі зміни в освітній системі можуть деструктивно змінити потоки інформації і призвести до негативних наслідків.

Екологічний закон збереження стійкості 


\section{ШЛЯХИСТВОРЕННЯ ЕКОЛОГООРІЄНТОВАНОГО ОСВІТНЬОГО СЕРЕДОВИЩА У ЗАКЛАДАХ ВИЩОЇ ОСВІТИ}

системи, який Б. Коммонер трактує наступним чином: “... екосистема є єдиним цілим, в рамках якого нічого не може бути виграно або втрачено, і яка не може бути об'єктом загального поліпшення: все, що було вилучено з неї людиною для ㄲï потреб, повинно бути відшкодовано. Стосовно до екологоорієнтованого освітнього середовища, то ми повинні розуміти, що освітнє середовище як соціальний об'єкт має власні умови функціонування і порушення цих умов може призвести до непоправних наслідків. Елементи новизни повинні бути органічно пов'язані з уже існуючими елементами у цілісну систему, не завдаючи їй шкоди і не руйнуючи іiі.

Екологічний закон, який Б. Коммонер сформулював для природних систем, що взаємодіють 3 техносферою був "Все повинно кудись зникати”. Трактувати йомо можна наступним чином: все, що функціонує і зазнає розвитку, продукує різні відходи - матеріальні, енергетичні, інформаційні і т.д. Ці “відходи” порушують ефективне функціонування екологічних систем. Природне середовище передбачає постійний саморозпад і самоочищення, що передбачає наявність консументів, редуцентів, дентритофагів, копрофагів, некрофагів. Людська цивілізація стикається 3 тими чи іншими наслідками порушення цього закону у природньосоціальних екологічних системах. Що торкається освітнього простору, то зараз, у епоху четвертої техногенної революції ці “відходи” в більшій мірі пов'язані з діями людини і становлять для неї в тій чи іншій мірі проблеми і загрози.

Підсумовуючи вищесказане, можна виокремити щонайменше два напрями в контексті реалізації створення екологоорієнтованого середовища у 3ВО: "проектуванняЗВОякцентрівекологоорієнтованого інноваційного освітнього середовища”, “підвищення конкурентноздатності професійної освіти у ЗВО”

Екологоорієнтоване освітнє середовище у ЗВО повинно, на нашу думку, базуватись на комплексі заходів, спрямованих:

- на створення еколоорієнтованого освітнього простору; на функціонування освітнього процесу 3 урахуванням соціоекології середовища; створення сприятливого екосередовища, рекреаційного простору $3 \mathrm{BO} з$ допомогою певних лікарських і кімнатних рослин і т.д.

Термін “екосистема” запозичений з класичної екології і виходячи з цього, ми припускаємо, що така складна система як освітнє середовище також $\epsilon$ екосистемою, що функціонує шляхом взаємодії елементів, між якими також йде постійний обмін речовинами (матеріальний, господарсько-фінансовий, забезпечення освітньої діяльності), енергією (джерела енергії, біоенергетичний забезпечення: взаємодія тих, хто вчить і навчається, розвиток творчого потенціалу, самоактуалізацією, взаємодією з зовнішнім середовищем) і інформацією (інформаційнохмарне забезпечення освітньої діяльності, інформаційно-освітнє середовище, дистанційне освітнє середовище). Звичайно, існують прості і складні екосистеми, відповідно прості і складні освітні середовища у освітні системи, що об'єднуються у єдиний освітній простір країни, а він об'єднується завдяки процесам глобалізації у глобальний освітній простір.

В контексті змін освітньої парадигми Євросоюзу важливу увагу зосереджують на створенні у ЗВО трикутника інноваційного освітнього середовища “знання - освіта дослідження(інноваціі), зокрема це окреслено у Лісабонській стратегії розвитку (2006). Заклади вищої освіти відіграють центральну роль у формуванні інноваційного освітнього середовища, і хоча всі три компоненти інноваційного процесу залишаються автономними, вони доповнюють, взаємодіють і функціонують у просторі 3ВО.

Таким чином, підсумовуючи вищесказане, можна зробити наступні висновки:

1. Вирішення проблеми підвищення ефективності професійної освіти має базуватися на забезпеченні екологоорієнтованості освітнього середовища і розвитку інноваційного освітнього середовища, в перспективі екологооріснтованого; функціонування системи підготовки фахівців в університеті слід поєднувати 3 забезпеченням розвитку інноваційних середовищ “освітнє середовище наукове середовище - середовище бізнесу” 3 метою підвищення якості освіти, розуміння вимог ринку праці;

Подальший розвиток викладених в статті проблем авторами буде спрямовано на наукові дослідження, що допоможуть поглибити знання про структуру освітнього екологоорієнтованого середовища в напрямі формування професійних компетенцій і компетентностей випускників під потреби професійних стандартів та ринку праці.

\section{ЛIТЕРАТУРА}

1. Артюхина А. И. Образовательная среда высшего учебного заведения как педагогический феномен : моногр. Волгоград, 2006. 237 с.

2. Артюхина А. И. Образовательная среда высшего учебного заведения как педагогический феномен (на материале проектирования образовательной среды медицинского университета) : дис. ... доктора пед. наук : 13.00.08. Волгоград, 2007. 377 с.

3.Верхоглядова Н.І., Марценовський В.О. Якість освітніх послуг - головний чинник 


\section{ШЛЯХИ СТВОРЕННЯ ЕКОЛОГООРІЕНТОВАНОГО ОСВІТНЬОГО СЕРЕДОВИЩА}

У ЗАКЛАДАХ ВИЩОЇ ОСВІТИ

освітніх послуг - головний чинник конкурентоспроможності навчальних закладів. Тези доп. регіонал. наук.-практ. конф. "Неперервна освіта: проблеми, рішення, перспективи” м. Дніпропетровськ, 15-16 квіт. 2005. Дніпропетровськ. 2005. С. 41-42.

4. Маркович Д. Ж. Социальная экология : кн. для учителя; пер. с сербохорв. О. И. Долгой. Москва, 1991. $173 \mathrm{c}$.

5. Микитюк О. М. Зачепа А.М, Никитюк Г.П Шляхи використання компетентнісного підходу у процесі навчання студентів-магістрів у закладах вищої освіти. Молодь іринок. Дрогобич, № 7 (174), 2019. С. 6-11.

6. ДурнякБ.В., МикитюкО.М., Угрин Я.М., Зачепа А.М., Майба Т.М. Впровадження компетентнісного підходу у освітній простір закладів вищої освіти: колективна монографія. Львів. Укр. Акад.. друкарства.2019. 224 с.

7. Олейников Б. В., Подлесный С. А. О концепции “экосистема обучения" и направлениях информатизации образования. Знание. Понимание. Умение. 2013. № 4. С. 84-91.

8. Індекс Глобальної конкурентоспроможності 20122013. URL: http://ung.in.ua/ua/news/62/. 3

9. Ясвин В.А. Образовательная среда: от моделирования к проектированию. Москва, 2001. 365 с.

10. Brodo J. A. Today's Ecosystem of Elearning. Trainer Talk. 2006. Vol. 3. №4. URL: http://enewsbuilder.net/ salesmarketing/e article000615779.cfm

11. Dong B., Zheng Q., Yang J., Li H., Qiao M. An Elearning Ecosystem Based on Cloud Computing Infrastructure. The Ninth IEEE International Conference on Advanced Learning Technologies. (Riga, 15-17 July 2009). Riga, Latvia. ICALT 2009. P. 125-127.

12. Education at a Glance 2012: OECD Indicators, OECD Publishing. URL: http://dx.doi.org/10.1787/eag2012-en.

13. Higher Education Institutions in Europe. Report to the European Commission. URL: http://www.utwente.nl/ cheps/documenten/engreport05institutional profiles. pdf.

14. Marijk van der Wende. European Responses to Global Competitiveness in Higher Education. Marijk van der Wende. Amsterdam University. URL: http://www www.oecd.org/

\section{REFERENCES}

1. Artuchina, A. I. (2006). Obrazovatelnaj sreda vusshego ychebnogo zavedenia kak pedagogicheskiy phenomen [The educational environment of a higher educational institution as a pedagogical phenomenon]. Volgpgrad, 237 p. [in Russian].

2. Artuchina, A.I. (2007). Obrazovatelnaj sreda vushego ucebnogo zavedenis kak pedagogicheskiy phenomen [The educational environment of a higher educational institution as a pedagogical phenomenon (based on the design of the educational environment of a medical university)]. Volgograd, 377 p. [in Russian].

3. Verchogladova, N.I. (2005). Yakist osvitnich poslug - golovniy chinnik konkurentnospromochnosti navchalnich zakladiv [The quality of educational services is a major factor in the competitiveness of educational institutions]. Dnipropetrovsk, pp. 41-42. [in Ukrainian].

4. Marcovich, D.Z. (1991). Socialna ecologia [Social ecology]. Moscow, 173 p. [in Russian].

5. Mukutiyk, O. M., Zachepa, A.M. \& Nikitiuk, H.P. (2019). Slachu vukorustanna kompetentnisnogo pidchody y procesi navchanna studentiv-magistrantiv y zakladach wichoi osvity [Ways to use a competency-based approach in the process of teaching undergraduate students in higher education institutions]. Youth \& market, No. 7 (174), pp. 6-11. [in Ukrainian].

6. Dyrniak, B.V., Mykytyuk, O.M., Ygrin, J.M., Zachepa,A.M. \& Majba, T.V. (2019). Vprovadzenna kompetentnisnogo pidcody $y$ osvitniy prostir [Implementation of the competence approach in the educational space of higher education institutions]. Lviv, 224 p. [in Ukrainian].

7. Olejnicov, B. V. \& Podlesniy B.V. (2013). O consepsiy ecosistema obychenia i napravleniach informatizacii obrazovania [On the concept of "learning ecosystem" and the directions of computerization of education]. Knowledge. Understanding. Skill. No. 4. pp. 84-91. [in Russian].

8. Indeks Globalnoi konkyrentnospromochnosti 20122013 [Yandex Global Competitiveness 2012-2013]. Available at: http://ung.in.ua/ua/news/62/. 3 [in Ukrainian].

9. lasvin V.A. (2001) obrazovatelnaya sreda ot modelirovania do proectirovania [Educational environment: from modeling to design]. Moscow, 365 p. [in Russian].

10. Brodo, J. A. (2006). Today's Ecosystem of Elearning. Trainer Talk. Vol. 3. No.4. Available at: http:// e n e w s build e r. n e t/s a le s marketi ng/ e article000615779.cfm[in English].

11. Dong, B., Zheng, Q., Yang, J., Li, H. \& Qiao, M. An Elearning Ecosystem Based on Cloud Computing Infrastructure. The Ninth IEEE International Conference on Advanced Learning Technologies. (Riga, 15-17 July 2009). Riga, Latvia. ICALT 2009.pp. 125-127. [in English].

12. Education at a Glance 2012: OECD Indicators, OECD Publishing. Available at: http://dx.doi.org/10.1787/ eag-2012-en. [in English].

13. Higher Education Institutions in Europe. Report to the European Commission. Available at: http:// w w w . u t w e n t e. n l/cheps/documente n/ engreport05institutional profiles. pdf. [in English].

14. Marijk van der Wende. European Responses to Global Competitiveness in Higher Education. Marijk van der Wende. Amsterdam University. Available at: http:// www www.oecd.org/ [in English].

Стаття надійшла до редакції 05.11.2019

\section{GS8080

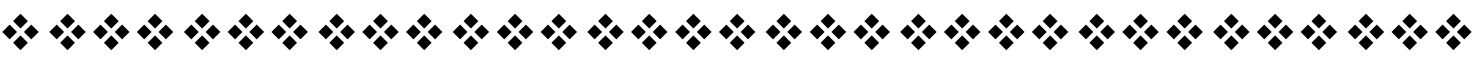

